\title{
Developing Education Profession Ethics Among Pre-services Teachers: Kohlberg Modeled Training Program Intervention
}

\author{
Nisreen M. Al-Disi ${ }^{1 *} \quad$ Saleh M. Rawadieh ${ }^{2}$ \\ 1.School of Educational Sciences, The University of Jordan, P.O. Box 11942, Amman, Jordan \\ 2. Department of Educational Sciences, College of Education, Qatar University, Qatar
}

\begin{abstract}
This study aimed to identify the effectiveness of a training program based on Kohlberg Moral Growth Theory in the development of education profession ethics among pre-service teachers at the School of Educational Sciences at the University of Jordan. The study population consisted of (134) classroom teacher students in the academic year 2018/2019. Randomly, (30) students were assigned as the experimental group and (30) students as the control group. Moral judgment scale developed by Al-Disi and Rawadieh (2019) was used to measure moral judgement of education profession ethics. The training program consisted of (6) modules in accordance with Kohlberg. The experimental group joined the ethics training program for two months. Results showed that the training program was (71\%) effective in the development of the education profession ethics among the experimental group. The researchers recommended investing the training program in developing a curriculum course of education profession ethics for pre-service teachers.
\end{abstract}

Keywords: Kohlberg, Pre-Service Teachers, Training Program, Education Profession Ethics, Jordan.

DOI: $10.7176 / \mathrm{JEP} / 11-2-04$

Publication date: January $31^{\text {st }} 2020$

\section{Introduction}

Several studies conducted from the late 1980s to early 2000 indicate that basic ethical principles in pre-service teacher training programs were lower than those of university students in other disciplines (Yeazell \& Johnson, 1988; Lampe, 1994; McNeel, 1994; Cummings, Dyas, Maddux, \& Kochman, 2001). In addition, some studies have shown a clear reduction in the moral judgment of students enrolled in teacher preparation programs from the first to the fourth year (Lampe, 1994; McNeel, 1994).

Few empirical studies have specifically examined the effectiveness of ethical training programs in education (Winston, 2007). Moreover, most of the researches and educational studies have been exposed to the different strategies that universities currently use to integrate ethics in the curriculum or in the classroom. Cummings found that moral judgment can be made through intentional educational interventions, such as ethics courses. These courses used to discuss ethical dilemmas and explained that there is no real difference between using virtual dilemmas rather than real ones (Cummings, Maddux, Richmond, \& Cladianos, 2010).

Teachers face ethical quandaries bombarding them every day in their professional life. Reports reveal unprofessional behavior among teachers. To adequately deal with these challenges teachers must get trained in professional ethics. However, evidences suggest inadequate attention is paid to ethics training in teacher education programs (Kumar, 2015).

\subsection{Kohlberg moral growth theory}

Kohlberg identified three levels of moral development: pre-conventional, conventional and post-conventional. Each level has two distinct stages. During the conventional level, the child's sense of morality is controlled from the outside. Children accept and believe rules of authority, such as parents and teachers, and judge any action based on its consequences. During the conventional level, one's sense of morality is linked to personal and social relationships. Children continue to accept the rules of power, but this is now because they believe this is necessary to ensure positive relationships and social order. During the post-conventional level, a person's sense of morality is defined in terms of abstract principles and values. People now believe that some laws are unfair and should be changed or repealed. Kohlberg found that a person's ability to deal with ethical issues does not form simultaneously. Just as there are stages of growth in physical development, the ability to think ethically also evolves in stages (Kohlberg, 1984).

Kohlberg's theory of moral development assumes that moral thinking is not fixed, but a person is able to move from one stage to another. So, each individual has the ability to move to higher stages of Kohlberg when faced with moral dilemmas (Kohlberg, 1981).

\subsection{Literature review}

Many educators argue that teacher training programs should use an applied ethics approach that uses case studies to engage students in thinking about realistic scenarios as a means of linking practical dilemmas to theory and ethical principles (Soltis, 1986; Shapiro \& Stefkovich, 2011). Teacher training through graduation in the courses 
of the National Education Association Code of Ethics (National Education Association, 1975). Ethical law contains the basic responsibilities and principles that all teachers must follow. However, most researchers discourage the use of the Code of Ethics as the sole subject for teaching ethical methodology; some believe it is effective as a basis for ethical training (Soltis 1986; Watras, 1986).

Research findings indicate that students of education colleges are leaving colleges and universities with an unclear understanding of what is expected of them by society, peers and their profession. The way in which teachers are prepared in terms of the ethical dimensions of their profession is inconsistent with the general orientation of the professionalization of the education profession, and is incompatible with the importance of professional codes of conduct (Maxwell, 2017).

However, the controversy question "Can Ethics Be Taught?" is about 2,500 years old. The philosopher Socrates discussed this issue with his Athenian colleagues. Socrates' answer was clear: ethics consists of knowing what to do, and this knowledge can be taught. Most psychologists today agree with Socrates. Much of Rest's research has been done by Harvard's late psychologist, Lawrence Kohlberg. Kohlberg was one of the first to seriously consider whether a person's ability to deal with ethical issues could develop later in life and whether education could influence that development (Rest, 1986).

Ethics training programs that uses games showed significantly decreases respondents' importance rating on issues associated with lower stages of an individual's cognitive moral development (CMD) and increases their importance rating on issues associated with the highest stage of CMD. In addition, a game-based ethics training program was found to produce significantly greater change on the importance rating towards issues associated with the middle stage of CMD than a non-game based ethics training program (Wenyeh \& Jonathan, 2018).

Engaging classroom activity that facilitates student learning about Kohlberg's theory of moral development by using digital resources to foster active, experiential learning was validated. In addition to hearing a standard lecture about moral development, students watched a video of a morally provocative incident, then worked in small groups to classify user comments posted in response to the video according to Kohlberg's six stages (Carmichael, et. al., 2018).

\subsection{Research goal and research questions}

In a reference study on "Policies for Teacher Training and Recruitment: The Jordanian Case", the revised studies unanimously found deficiencies in pre-service teacher training programs, whether in the colleges of education or other college programs, in-service training programs, in the policies of hiring teachers were . These deficiencies and obstacles constitute the main challenge facing the Jordanian educational system and must be addressed seriously and consciously to develop the Jordanian education system and improve its results (Al Sawalmeh, 2014).

According to a recent study performed by Al-Disi and Rawadieh (2019), the prevailing moral judgment of pre-service teachers was found at the second level (conventional morality) of Kohlberg. Significant differences were found in the moral judgment stages attributable to the student academic achievement and enrolled program. The researchers urged for further studies in pre-service teachers' education at the University of Jordan to increase teachers moral judgment during the practice of education profession.

When reviewing the previous literature, the importance of good teacher preparation on the education profession ethics was elucidated. This study is important because it expands Kohlberg's theory to the provision of training programs in the education field. Hence, this study came as an attempt to answer the following key question:

Is a training program based on Kohlberg moral growth theory effective in the development of education profession ethics among pre-service teachers at the University of Jordan?

The main question is divided into the following sub-questions:

1. What are the education profession ethics to be developed by pre-service teachers at the University of Jordan?

2. What is the framework of the training program to be delivered to pre-service teachers at the University of Jordan? 3 . What is the moral judgement of pre-service teachers at the University of Jordan?

4. Are there statistically significant differences $(\alpha=0.05)$ in the moral judgement of pre-service teachers at the University of Jordan due to the students' academic achievement?

5. Is the training program effective in the development of education profession ethics among pre-service teachers at the University of Jordan?

6. Does the effectiveness of the training program in the development of education profession ethics of pre-service teachers at the University of Jordan vary by the students' academic achievement?

\section{Method}

The researchers used the descriptive analytical method to prepare the education profession ethics to be developed by pre-service teachers and to develop the training program in accordance with Kohlberg Theory.

The researchers used the semi-experimental approach to examine the effectiveness of the developed training program. The experimental group was subject to the developed training program, in addition to the supervision of the supervisor of practical education (2) course according to the regulations and instructions of the School of 
Educational Sciences at the University of Jordan. The control group was subject only to the supervision of the supervisor of practical education (2) course.

The practical education (2) course (No. 0832419) objective is to train student teachers of the classroom teacher program in cooperative schools, where the training includes a variety of skills such as lesson planning, teaching techniques, classroom management and assessment. The training is organized in phases, including school observation, classroom observation, partial application, and full implementation. This training is supervised by the cooperating teacher in the school in addition to the professors of the curriculum and instruction department and trainers in the practical education program.

\subsection{Participants}

The researchers selected purposively the study population as all fourth year students enrolled in the classroom teacher program at the University of Jordan in the second semester of the academic year 2018/2019. Total number of students were (134) according to the statistics of the Department of Admission and Registration at the University of Jordan. Distribution of the study population according to students' academic achievement is presented in Table (1).

Table 1: Distribution of the Study Population

\begin{tabular}{cccccc}
\hline \multicolumn{2}{c}{ Number of students } & \multicolumn{4}{c}{ Academic Achievement } \\
\hline \multicolumn{1}{c}{$\%$} & $\%$ & $\mathrm{f}$ & $\%$ & $\mathrm{H}$ & High \\
\hline 134 & $100 \%$ & 58 & $43.28 \%$ & 76 & $\% 56.72$ \\
\hline
\end{tabular}

To measure the effectiveness of the developed training program, the researchers selected a random sample of (60) students from the study population registered in the practical education (2) course in the University of Jordan. Students enrolled in this course are distributed to a range of cooperating schools, where the effectiveness of the training program can be observed in the practice field (schools). The distribution of students to the experimental and the control group was based on the official records of the Admission and Registration Unit at the University of Jordan. The researchers randomly assigned one section to the experimental group consisting of (30) students and another section as a control group consisting of (30) students.

\subsection{Procedure}

\subsubsection{Preparing education profession ethics to be maintained by study members}

For the purpose of this study, the researchers prepared a list of education profession ethics in accordance with the National Charter of the Education Profession Ethics (Ministry of Education, 2018), and the Ethical Charter of the Education Profession in the United States (Association of American Educators, 2018). Validity of the education profession ethics was conducted by presenting the list to a group of (10) referees cited with expertise and competence in the field of ethics and education to explore their views on the content, clarity of paragraphs, language and appropriateness with the study purpose. More than $(80 \%)$ of referees expressed the validity of the list content and that it is properly prepared according to the purpose of this study.

\subsubsection{Developing the training program}

The researchers developed the training program based on Kohlberg's Moral Growth Theory taking into account the following:

- The core objective of the training program is to train participants to reason. The reasoning processes carried out by the individual lead to the moral judgment that will be taken.

- The main components of the training program includes dynamic content, ethical dilemmas and games to motivate participants to reflect on their moral judgment.

- Provide in sequence and structured training content that is compatible with the realities of the field (schools) for study members.

- The training program supports the needs and is compatible with the culture of the study members and the community.

- $\quad$ Flexible training tools, instructions and reflective approach.

- Design the program in three levels as in Kohlberg Theory, and each level includes two stages, where the pre-service teacher moves between these stages in sequence.

The process of developing the training program included a series of processes organized according to the (ADDIE) model, which is a procedural framework for the design and development of training programs including: Analysis, Design, Development, Implement and Evaluate (Morrison, 2010).

The researchers conducted a preliminary evaluation of the training program by ensuring the validity of the training program and its suitability for the purpose of this study by presenting it to a group of (10) referees with competence and experience. All referees expressed the validity of the training program to achieve the study purpose.

Prior to the implementation of the training program, the researchers were keen to provide the appropriate 
training environment from the provision of the training room, tools, manuals, etc. One of the researchers took over the tasks of the trainer as she enjoys the personality of an inspiring trainer, in addition to her extensive experience in the field of adults training for more than (15) years.

The training program was administered to the study members for two months during the second semester of the academic year 2018/2019. Total training hours was (60) hours arranged in (40) training sessions. Each training session is for (90 minutes). Participants attend the training program for two days every week, and for two training sessions per day (with 30 minutes break). During training program administration, the researchers conducted direct observations of a random sample of the study members from the experimental and the control group in the cooperating schools.

\subsection{Data Collection Tool}

The researchers used the Moral Judgement Scale developed by Al-Disi and Rawadieh (2019) to measure the moral judgement of education profession ethics of the classroom teacher students involved in this study. The scale consists of five dilemmas related to education profession ethics. Each of the five dilemmas is followed by some questions related to different aspects of the situation. The respondent is asked to select the most appropriate answer (multiple choice) from the six offered options (A, B, C, D, E, and F) which is in agreement with the respondent thinking. The moral judgment of the student is estimated by the total scale score which ranges from (20) as the minimum score up to (120), as the maximum score.

The moral judgment scale was administered directly to the control and experimental group. After scale completion, scales were collected, scored and analyzed. This administration process was applied to the study members in the experimental and in the control group prior and post training program implementation.

The researchers organized (80) visits to the study members from the experimental and the control group in four co-operative schools (two schools for the experimental group and two schools for the control group). The time of the visit ranged from (15) minutes to (45) minutes. The researchers made these visits to observe the study members in the actual filed of practicing the education profession and to observe the extent of the trainees' adherence to the education profession ethics. In addition, the researchers were keen to communicate directly with the school administration, and the cooperating teacher responsible for each student teacher in order to collect as much information as possible on the performance of trainees for the purpose of this study.

\subsection{Confidentiality}

The researchers briefed all study participants on the study objectives and data collection tools before participating in the study. The researchers assured all participants of confidentiality and the right to withdraw from the study at any time.

\subsection{Research Design}

This study included the following variables:

- Independent variable: represented by the training program developed by the researchers based on Kohlberg Moral Growth Theory.

- Dependent variable: represented by the education ethics profession which the training program (independent variable) aimed to develop among the study participants.

- Moderator Variable: represented by the classification of the study members according to their academic achievement (GPA) based on their cumulative rates according to the data of the Department of Admission and Registration at the University of Jordan as follows: Low academic achievement: GPA (2.56 $\leq$ ); High academic achievement: GPA $(2.57 \geq)$.

Following is the study design:

$\left(\begin{array}{ll}\text { EG: } & \text { O1 X O1 } \\ \text { CG: } 01 & \text { O1 }\end{array}\right) \quad \begin{aligned} & \text { EG: Experimental Group } \\ & \text { CG: Control Group }\end{aligned}$

$\mathrm{X}$ : Treatment; enroll experimental group in the ethics training program

O1: Pre- and Post- application of the moral judgment scale

\subsection{Data Analysis}

Frequency and percentage of pre-service teachers' responses on the Moral Judgment Scale were used to analyze both moral judgment level and moral judgment stage. Mann-Whitney test was used to compare mean ranks of the moral judgment levels and stages of education profession ethics according to the academic achievement variable.

Means and standard deviations of pre-service teachers' responses were calculated upon applying the pre- and post-moral moral judgment scale according to the academic achievement variable for both the experimental and control groups. To determine whether the differences between the means were statistically significant at the level of significance $(\alpha=0.05)$, the common variance analysis (ANCOVA) was applied. To reveal the differences in the pre-service teachers' performance on the moral judgment scale depending on the group type (experimental and 
control), the estimated marginal means and standard errors were extracted. The Mann-Whitney test was used to compare the rank means for the moral judgment level of pre-service teachers' according to the academic achievement variable.

\section{Results}

3.1 Research Study Sub-question 1: What are the education profession ethics to be developed by pre-service teachers at the University of Jordan?

The developed education profession ethics consisted of a set of professional ethics to be developed by the study members organized in three levels, and each level includes two stages of moral judgment as illustrated in Table (2).

Table 2: Education Profession Ethics for Pre-service Teachers

\begin{tabular}{|c|c|c|}
\hline Level & Stage & Education Profession Ethics \\
\hline \multirow{4}{*}{$\begin{array}{l}\text { One: } \\
\text { Professional } \\
\text { ethics before } \\
\text { practicing } \\
\text { education } \\
\text { profession }\end{array}$} & One: Teacher ethics & - The teacher understands the foundations of the ethics of the teaching \\
\hline & $\begin{array}{l}\text { towards the } \\
\text { teaching profession }\end{array}$ & $\begin{array}{l}\text { profession. } \\
\text { - The teacher understands the limits and limitations of education } \\
\text { profession. } \\
\text { - The teacher appreciates the importance of abiding by the laws and } \\
\text { regulations governing education profession. }\end{array}$ \\
\hline & Two: Teacher ethics & - The teacher accepts accountability for his practices and \\
\hline & $\begin{array}{lr}\text { towards } & \text { his } \\
\text { practices } & \text { and } \\
\text { performance } & \end{array}$ & $\begin{array}{l}\text { performance. } \\
\text { - The teacher recognizes the importance of professional development. }\end{array}$ \\
\hline
\end{tabular}

\begin{tabular}{|c|c|c|}
\hline \multirow[t]{2}{*}{$\begin{array}{l}\text { Two: } \\
\text { Professional } \\
\text { ethics during } \\
\text { the practice of } \\
\text { the education } \\
\text { profession }\end{array}$} & $\begin{array}{l}\text { Three: } \\
\text { ethics } \\
\text { students }\end{array}$ & $\begin{array}{l}\text { - The teacher is keen to observe the rights and duties of the student. } \\
\text { - The teacher is committed to work within the basis of the teacher } \\
\text { relationship with students. } \\
\text { - The teacher is dedicated to provide a safe environment for learning. } \\
\text { - The teacher maintains the professional limits of the teacher } \\
\text { relationship with students and its determinants. } \\
\text { - The teacher is committed to the ethical behavior that must be } \\
\text { committed towards his students. }\end{array}$ \\
\hline & $\begin{array}{l}\text { Four: Teacher ethics } \\
\text { towards the school } \\
\text { community }\end{array}$ & $\begin{array}{l}\text { - The teacher is keen to commit to the rights and duties of the school } \\
\text { community. } \\
\text { - The teacher works within the foundations of the teacher relationship } \\
\text { with fellow teachers. } \\
\text { - The teacher is committed to work within the basis of the teacher } \\
\text { relationship with the school administration. } \\
\text { - The teacher maintains the professional limits of the teacher } \\
\text { relationship with the school community and its determinants. } \\
\text { - The teacher is committed to the ethical behavior that must be } \\
\text { committed towards the school community. }\end{array}$ \\
\hline \multirow[t]{2}{*}{$\begin{array}{l}\text { Three: } \\
\text { Professional } \\
\text { ethics after } \\
\text { practicing } \\
\text { education } \\
\text { profession }\end{array}$} & $\begin{array}{lr}\text { Five: Teacher ethics } \\
\text { towards student } \\
\text { family } \\
\text { community }\end{array}$ & $\begin{array}{l}\text { - The teacher maintains the professional limits of the teacher } \\
\text { relationship with the student family and its determinants in terms of } \\
\text { rights and duties. } \\
\text { - The teacher maintains the professional limits of the teacher } \\
\text { relationship with the community in terms of rights and duties. } \\
\text { - The teacher is committed to the ethical behavior that must be } \\
\text { committed towards the student family and the community. }\end{array}$ \\
\hline & $\begin{array}{l}\text { Six: Teacher ethics } \\
\text { towards humanity }\end{array}$ & $\begin{array}{l}\text { - The teacher applies equality and justice. } \\
\text { - The teacher has human morality. }\end{array}$ \\
\hline
\end{tabular}

3.2 Research Study Sub-question 2: What is the framework of the training program to be delivered to the preservice teachers at the University of Jordan?

The developed training program included (6) modules in accordance with Kohlberg Moral Growth Theory and the list of education profession ethics to be developed by study members as illustrated in Table (3). 
Table 3: Training Program Framework

\begin{tabular}{|c|c|c|c|c|}
\hline \multicolumn{2}{|c|}{ Kohlberg Moral Growth Theory } & \multicolumn{2}{|c|}{ Education Profession Ethics } & \multirow{2}{*}{$\begin{array}{l}\text { Training Program } \\
\text { Module }\end{array}$} \\
\hline Level & Stage & Level & Stage & \\
\hline \multirow{3}{*}{$\begin{array}{l}\text { One: } \\
\text { Conventional } \\
\text { Morality }\end{array}$} & One: Rewards and & \multirow{3}{*}{$\begin{array}{lr}\text { One: Professional } \\
\text { ethics } \quad \text { before } \\
\text { practicing } \\
\text { education } \\
\text { profession }\end{array}$} & One: Teacher ethics & One \\
\hline & Punishment & & $\begin{array}{l}\text { towards the } \\
\text { teaching profession }\end{array}$ & \\
\hline & $\begin{array}{ll}\text { Two: } & \text { Simple } \\
\text { Reciprocity } & \end{array}$ & & $\begin{array}{l}\text { Two: Teacher } \\
\text { ethics towards his } \\
\text { practices and } \\
\text { performance }\end{array}$ & Two \\
\hline \multirow[t]{2}{*}{$\begin{array}{l}\text { Two: Conventional } \\
\text { Morality }\end{array}$} & $\begin{array}{l}\text { Three: Social } \\
\text { Approval/Personal } \\
\text { Relationships }\end{array}$ & \multirow{2}{*}{$\begin{array}{l}\text { Two: Professional } \\
\text { ethics during the } \\
\text { practice of the } \\
\text { education } \\
\text { profession }\end{array}$} & $\begin{array}{ll}\text { Three: } & \text { Teacher } \\
\text { ethics } & \text { towards } \\
\text { Students } & \\
\end{array}$ & Three \\
\hline & $\begin{array}{l}\text { Four: Upholding / } \\
\text { enforcing norms and } \\
\text { Laws }\end{array}$ & & $\begin{array}{l}\text { Four: Teacher } \\
\text { ethics towards the } \\
\text { school community }\end{array}$ & Four \\
\hline \multirow[t]{2}{*}{$\begin{array}{l}\text { Three : Post- } \\
\text { Conventional } \\
\text { Morality }\end{array}$} & $\begin{array}{l}\text { Five: Broad Social } \\
\text { Contract Issues }\end{array}$ & \multirow{2}{*}{$\begin{array}{l}\text { Three: Professional } \\
\text { ethics after } \\
\text { practicing } \\
\text { education } \\
\text { profession }\end{array}$} & $\begin{array}{l}\text { Five: } \quad \text { Teacher } \\
\text { ethics towards } \\
\text { student family and } \\
\text { community }\end{array}$ & Five \\
\hline & $\begin{array}{l}\text { Six: Universal } \\
\text { Principles } \\
\text { (Humanity) }\end{array}$ & & $\begin{array}{l}\text { Teacher ethics } \\
\text { towards humanity }\end{array}$ & Six \\
\hline
\end{tabular}

Each training module has a rich content aiming to achieve the objective of the training program. Training topics are illustrated in Table (4).

Table 4: Training Program Topics

\begin{tabular}{|c|c|}
\hline Module & Topics \\
\hline $\begin{array}{l}\text { One: Teacher Ethics } \\
\text { towards the Teaching } \\
\text { Profession }\end{array}$ & $\begin{array}{l}\text { - Principles of professional ethics } \\
\text { - Principles of the education ethics } \\
\text { - Teacher profession limits and determinants } \\
\text { - Laws and regulations governing the education ethics profession }\end{array}$ \\
\hline $\begin{array}{ll}\text { Two: Teacher } & \text { Ethics } \\
\text { towards } & \text { Career } \\
\text { Development } & \\
\end{array}$ & $\begin{array}{l}\text { - Accountability concept } \\
\text { - The importance of teacher professional development }\end{array}$ \\
\hline $\begin{array}{l}\text { Three: Teacher Ethics } \\
\text { towards Students }\end{array}$ & $\begin{array}{l}\text { - The rights and duties of the student } \\
\text { - The principals of the teacher-student relationship } \\
\text { - Safe environment (educational and learning) } \\
\text { - The limits of the teacher-student relationship and its determinants. } \\
\text { - Ethical behavior of the teacher towards the students }\end{array}$ \\
\hline $\begin{array}{l}\text { Four: Teacher Ethics } \\
\text { towards the School } \\
\text { Community }\end{array}$ & $\begin{array}{l}\text { - The rights and duties of the school community } \\
\text { - The principals of the teacher and his colleagues relationship } \\
\text { - The principals of the teacher and school management relationship } \\
\text { - The limits of the teacher-school community relationship and its determinants. } \\
\text { - Ethical behavior of the teacher towards the school community }\end{array}$ \\
\hline $\begin{array}{l}\text { Five: Teacher Ethics } \\
\text { towards Student Family } \\
\text { and the Community }\end{array}$ & $\begin{array}{l}\text { - The limits of the teacher-parents relationship and its determinants } \\
\text { - The limits of the teacher- community relationship and its determinants. } \\
\text { - Ethical behavior of the teacher towards parents and the community }\end{array}$ \\
\hline $\begin{array}{lr}\text { Six: Teacher } & \text { ethics } \\
\text { towards } & \text { Human } \\
\text { Principles } & \\
\end{array}$ & $\begin{array}{l}\text { - The concepts of equality and justice } \\
\text { - The concept of humanity }\end{array}$ \\
\hline
\end{tabular}

The training program included many training activities (ethical games and ethical dilemmas) that were prepared and formulated by the researcher based on literature and previous studies in accordance with the purpose of this study. All activities focus on the moral reasoning of the study members and how to face the moral dilemmas they may encounter during the practice of the education profession. Training activities are applied on individual basis, two-peer groups and small groups (4-5) members through different strategies such as brainstorming, buzz group, coaching, debate, demonstration, dialogue, discussion, reflection, role play, simulation, etc. The training program included (90) training activities; (40) ethical dilemmas and (50) ethical games. 
3.3 Research Study Sub-question 3: What is the moral judgement of pre-service teachers at the University of Jordan?

The frequency and percentage of students' responses on the Moral Judgement Scale (Al-Disi \& Rawadieh, 2019) were calculated as presented in table (5) and table (6).

Table 5: Moral Judgment Level of Pre-service Teachers $(n=134)$

\begin{tabular}{lcc}
\hline & \multicolumn{2}{c}{ Students } \\
\hline Moral Judgment Level & f & \% \\
\hline First Level : Pre-Conventional Morality & 0 & $0 \%$ \\
\hline Second Level : Conventional Morality & 103 & $89.6 \%$ \\
\hline Third Level : Post-Conventional Morality & 12 & $10.4 \%$ \\
\hline
\end{tabular}

f: frequency; \%: percentage

Table 6: Moral Judgment Stage of Pre-service Teachers $(n=134)$

\begin{tabular}{lcc}
\hline & \multicolumn{1}{c}{ Students } \\
\hline Moral Judgment Stage & f & $\%$ \\
\hline Stage One: Rewards and Punishment & 0 & $0 \%$ \\
\hline Stage Two: Simple Reciprocity & 0 & $0 \%$ \\
\hline Stage Three: Social Approval/Personal Relationships & 30 & $26.1 \%$ \\
\hline Stage Four: Upholding / enforcing norms and laws & 73 & $63.5 \%$ \\
\hline Stage Five: Broad Social Contract Issues & 12 & $10.4 \%$ \\
\hline Stage Six: Universal Principles & 0 & $0 \%$ \\
\hline
\end{tabular}

f: frequency; \%: percentage

Table (5) shows that the prevailing moral judgment level among the classroom teacher program is the second level, the "Conventional Morality" level of Kohlberg with (103) students for (89.6\%). While, (12) students with $(10.4 \%)$ were found at the third level, the "Post-Conventional Morality" level of Kohlberg. However, no students appeared in the first level, the "Pre-Conventional Morality" level of Kohlberg.

Table (6) shows that stage (4) of Kohlberg "Upholding/enforcing norms and laws" is the dominant stage with (73) students contributing to (63.5\%) of the total students. The third stage of Kohlberg "Social Approval/Personal Relationships" came at the second stage rank with (26.1\%), and the fifth stage of Kohlberg, the "Broad Social Contract Issues" came at the third rank with $(10.4 \%)$ of the total students. However, no students appeared in "stage one", "stage two" nor in "stage six" of Kohlberg moral judgement.

3.4 Research Study Sub-question 4: Are there statistically significant differences $(\alpha=0.05)$ in the moral judgement of pre-service teachers at the University of Jordan due to the students' academic achievement?

Mann-Whitney test was used to compare the means of the moral judgement level and moral judgment stage according to the academic achievement variable, as illustrated in Table (7) and Table (8) respectively.

Table 7: Moral Judgment Level Differences according to Students' Academic Achievement

\begin{tabular}{cccccc}
\hline Academic Achievement & Number & $\begin{array}{c}\text { Mean } \\
\text { Rank }\end{array}$ & $\begin{array}{c}\text { Sum } \\
\text { of Ranks }\end{array}$ & U value & Level of significance \\
\cline { 1 - 4 } Low & 51 & 52.00 & 25029 & 1326 & $.001^{*}$ \\
\hline High & 64 & 62.78 & 34656 & & \\
\hline
\end{tabular}

*Statistically significant at the level of $(\alpha=0.05)$

Table 8: Moral Judgment Stage Differences according to Students' Academic Achievement

\begin{tabular}{cccccc}
\hline $\begin{array}{c}\text { Academic } \\
\text { Achievement }\end{array}$ & Number & $\begin{array}{c}\text { Mean } \\
\text { Rank }\end{array}$ & $\begin{array}{c}\text { Sum } \\
\text { of Ranks }\end{array}$ & U value & $\begin{array}{c}\text { Level of } \\
\text { significance }\end{array}$ \\
\hline Low & 51 & 36.71 & 1872.00 & 546 & $.000^{*}$ \\
\hline High & 64 & 74.97 & 4798.00 & & \\
\hline
\end{tabular}

*Statistically significant at the level of $(\alpha=0.05)$

As per the results presented in Table (7) and Table (8), there are statistically significant differences at $(\alpha$ $=0.05$ ) in the moral judgment between the "low academic achievement" and the "high academic achievement" students reference to Mann-Whitney value of (1326) at (0.001) significance level for the moral judgment level and a Mann-Whitney value of (546) at (0.000) significance level for the moral judgment level. Differences in students' moral judgment level and moral judgment stage were in favor of "high academic achievement" students. 
3.5 Research Study Sub-question 5: Is the training program effective in the development of education profession ethics among pre-service teachers at the University of Jordan? and;

Research Study Sub-question 6: Does the effectiveness of the training program in the development of education profession ethics of pre-service teachers at the University of Jordan vary by students' academic achievement?

The mean and standard deviations of the responses of the classroom teacher students at the University of Jordan were calculated on the pre- and post-moral moral judgment according to the students' academic achievement as illustrated in Table (9).

Table 9: Pre- and Post- Moral Judgment Measurements for the Study Members

\begin{tabular}{|c|c|c|c|c|c|c|}
\hline \multirow{2}{*}{ Group } & \multirow{2}{*}{ Academic Achievement } & \multirow{2}{*}{ Number } & \multicolumn{2}{|c|}{$\begin{array}{l}\text { Moral Judgment } \\
\text { (Before Training) }\end{array}$} & \multicolumn{2}{|c|}{$\begin{array}{l}\text { Moral Judgment } \\
\text { (Post Training) }\end{array}$} \\
\hline & & & Mean & $\begin{array}{c}\text { Std. } \\
\text { Deviation }\end{array}$ & Mean & $\begin{array}{c}\text { Std. } \\
\text { Deviation }\end{array}$ \\
\hline \multirow{3}{*}{$\begin{array}{l}\text { Experimental } \\
\text { Group }\end{array}$} & Low & 13 & 60.77 & 5.805 & 75.00 & 6.298 \\
\hline & High & 17 & 73.82 & 4.707 & 85.12 & 4.820 \\
\hline & Total & 30 & 68.17 & 8.334 & 80.73 & 7.432 \\
\hline \multirow[t]{3}{*}{ Control Group } & Low & 13 & 60.77 & 5.231 & 65.77 & 6.193 \\
\hline & High & 17 & 74.18 & 4.773 & 77.06 & 5.437 \\
\hline & Total & 30 & 68.37 & 8.340 & 72.17 & 8.035 \\
\hline
\end{tabular}

Table (9) shows that there are apparent differences between the means of the students' responses on the moral judgment scale. To determine whether the differences between the means are statistically significant at the level of significance $(\alpha=0.05)$, Common Analysis of Variance (ANCOVA) was applied and the results are illustrated in Table (10).

Table 10: Moral Judgment ANCOVA Analysis

\begin{tabular}{lllllll}
\hline Source & $\begin{array}{l}\text { Type III Sum of } \\
\text { Squares }\end{array}$ & df & $\begin{array}{l}\text { Mean } \\
\text { Square }\end{array}$ & F & Sig. & $\begin{array}{l}\text { Partial Eta } \\
\text { Squared }\end{array}$ \\
\hline $\begin{array}{l}\text { Moral Judgment (Before } \\
\text { Training) }\end{array}$ & 1312.892 & 1 & 1312.892 & 154.253 & .000 & .737 \\
\hline Group & 1143.864 & 1 & 1143.864 & 134.393 & .000 & .710 \\
\hline Academic Achievement & 18.740 & 1 & 18.740 & 2.202 & .144 & .038 \\
\hline $\begin{array}{l}\text { Group * Academic } \\
\text { Achievement }\end{array}$ & 2.575 & 1 & 2.575 & .303 & .585 & .005 \\
\hline Error & 468.122 & 55 & 8.511 & & & \\
\hline Corrected Total & 4574.850 & 59 & & & & \\
\hline
\end{tabular}

Table (10) shows there are statistically significant differences at the level $(\alpha=0.05)$ in the students moral judgment according to the group variable, based on the calculated value of $F$ (134.393) with a level of significance $(\alpha=0.000)$, which is a statistically significant value. Accordingly, there is an impact of the training program in the level of moral judgment of the classroom teacher students at the University of Jordan. To find out the degree of the impact, the ETA square (2) was calculated, where it reached (0.710). As a result, (71\%) of the discrepancy between the experimental group and the control group is due to the training program.

Results in table (10) also shows that there are no statistically significant differences at the level of $(\alpha=0.05)$ in the moral judgment due to the interaction between the group and the students' academic achievement, as per the calculated value (q) of (.303) at the level of significance $(\alpha=0.585)$, which is not statistically significant. For this reason, there is no impact of interaction between the training program and the level of student' academic achievement.

In order to examine the differences in the students' moral judgment according to the group variable, the estimated marginal means and standard errors were calculated, as illustrated in Table (11).

Table 11: Moral Judgment Estimated Marginal Means

\begin{tabular}{|c|c|c|c|}
\hline Group & Academic Achievement & Mean & Std. Error \\
\hline \multirow[t]{3}{*}{ Experimental Group } & Low & $82.130^{\mathrm{a}}$ & .992 \\
\hline & High & $79.833^{\mathrm{a}}$ & .826 \\
\hline & Total & $80.982^{a}$ & .543 \\
\hline \multirow[t]{3}{*}{ Control Group } & Low & $72.900^{\mathrm{a}}$ & .992 \\
\hline & High & $71.438^{\mathrm{a}}$ & .840 \\
\hline & Total & $72.169^{a}$ & .541 \\
\hline
\end{tabular}

Referring to Table (10), the estimated marginal mean of the experimental group is higher than the estimated marginal mean of the control group. The estimated marginal mean of the experimental group on the post - 
application of the moral judgment scale was (80.982), while the estimated marginal mean of the control group on the post - application of the moral judgment scale was (72.169), which shows the effectiveness of the training program in the development of education profession ethics among pre-service teachers at the University of Jordan.

The researchers also observed the effectiveness of the training program by study members reflecting the exercises they received from the training program on practical application in the field. Many trainees showed a marked improvement in their relationships with students in accordance with the ethical rules and education profession ethics compared to the control group. This was also confirmed by the observations of the cooperating teachers in which student teachers performance differed from previous students. Trained student teachers ethical commitment to attend and implement various education profession duties was higher than un-trained students.

\section{Discussion}

Considering literature and previous studies, the researchers consider that education profession ethics to be developed by study members through intentional training program intervention structure can be conceived as Kohlberg envisages moral growth (as in Table 3); three levels of ethics education profession. The teacher moves from one level to another without exceeding any level and at different speeds dependent on the teacher. Thus, the first level was conceived as a foundation level that each teacher must pass through, which is the professional ethics before practicing the education profession, followed by the second level, which includes professional ethics during early practice of the teaching profession. Then the teacher must move to professional ethics after practicing the teaching profession for many years; Humanity.

Study results showed that most study members $(89.6 \%)$ were at the conventional morality level and within stage four $(63.5 \%)$ of Kohlberg moral judgment. These results are in accordance with previous studies (Shaheen \& Rimawi, 2015; Miqdadi, 2017), showing that moral reasoning levels in pre-service teachers at the University of Jordan are relatively low.

The study results also proved the efficiency of intentional training program intervention in the development of moral judgment among the study members. The efficiency was calculated as $71 \%$ efficient. The percentage of differences in the moral judgment of education profession ethics between the experimental and the control group is due to the better reflection of students, and their harmony with the training method, which reflected positively on their moral judgment results compared with the control group; who received only supervision of the practical education (2) course.

Study results were also in agreement with literature urging that ethics can be taught (Kumar, 2015), and that ethical training programs are effective in education (Winston, 2007). Ethical dilemmas included in the developed training program contributed to the training program efficiency as explored by Soltis (1986), Shapiro and Stefkovich (2011), Cummings, Maddux, Richmond, and Cladianos (2010). Furthermore, the researchers reflected the efficacy of the training program due to the presented content recognizing the actual ethical needs of the study members. In this context, the researchers reviewed the outline of Practical Education (2) course as well as the complete course plan of the classroom teacher program at the University of Jordan (2019) and perceived that ethics preparation is limited.

\section{Conclusion}

Pre-service teachers need to be trained to face ethical dilemmas and how to trigger moral judgment for education profession ethics. Ultimately, this will support and complement their professional capability. Face-face ethics training courses may be an appropriate approach to train future teachers on education profession ethics.

\section{Acknowledgments}

The researchers are grateful to Dr. Bassam Al Qudah, Dr. Maysoon Dwiri and Dr. Sahar Al Helow for validating the training program and support at various stages of the study. Special appreciation is for Prof. Nizar Al Halabi who conducted and verified the statistical analysis of the study results. A debt of thanks is also owed to the preservice teachers who participated in this study.

\section{References}

Al Sawalmeh, J. (2014). Teacher Training and Appointment Policies, The Jordanian Case, Arab Organization for Education, Culture and Science, Tunis and Queen Rania Teacher Training Academy, Jordan.

Al-Disi, N. and Rawadieh, S. (2019). Measuring Moral Judgment of Education Profession Ethics among Preservice Teachers of the School of Educational Sciences at the University of Jordan, International 12 (12): 71 - 84. doi:10.5539/ies.v12n12p71

Association of American Educators, Code of Ethics for Educators, https://www.aaeteachers.org/, retrieved date on November 14, 2018.

Cummings, R. Maddux, C. Richmond, A., and Cladianos, A. (2010). Moral reasoning of education students: The effects of direct instruction in moral development theory and participation in moral dilemma discussion. The 
Teachers College Record, 112 (3):621 - 644.

Cummings, R., Dyas, L., Maddux, C., and Kochman, A. (2001). Principled moral reasoning and behavior of preservice teacher education students. American Educational Research Journal, 38 (1): 143 - 158. doi:10.3102/00028312038001143

Kohlberg, L. (1981). Essays on moral development: Vol. 1, The philosophy of moral development. New York: Harper and Row.

Kohlberg, L. (1984). Essays on Moral Development, Vol. 2: The Psychology of Moral Development. CA: Harper \& Row ؛ Publishers, San Francisco, USA.

Kumar, J. (2015). An Approach to Professional Ethics Education for Pre Service Teachers, International Journal of Education and Applied Social Sciences, 6 (1): 61 - 67. DOI 10.5958/2230-7311.2015.00010.0

Lampe, J. (1994). Teacher education students' moral development and ethical reasoning process, Paper presented at the annual meeting of the American Educational Research Association, New Orleans, LA.

Maxwell, B. (2017). Codes of Professional Conduct and Ethics Education for Future Teachers, Philosophical Inquiry in Education, 24 (4): 323 - 347.

McNeel, S. (1994). College teaching and student moral development. In J.R. Rest \& D. Narvez (Eds.), Moral Development in the Professions: Psychology and applied ethics $(27-49)$. Hillsdale, NJ: Erlbaum.

Miqdadi, Y. (2015). Moral thinking and its relationship to full psychological existence and positive social behavior, Jordanian Journal of Educational Sciences, 11 (3), 269-284.

Morrison, G. (2010). Designing Effective Instruction, 6th Edition. John Wiley \& Sons.

National Education Association (1975). Representative Assembly, National Education Association Code of Ethics, Retrieved from http://www.nea.org/home/30442.htm.

Rest J. (1986). Moral Development. Advances in research and Theory. New York: Praeger.

Shaheen, A. and Rimawi, S. (2017). The level of ethical thinking among gifted and non-gifted students and its relationship to some variables in a Jordanian sample, Journal of Educational and Psychological Studies, 11 (2): $407-424$.

Shapiro, J. and Stefkovich, J. (2011). Ethical Leadership and Decision Making in Education: Applying Theoretical Perspectives to Complex Dilemmas, 3rd ed., New York, NY: Lawrence Erlbaum Associates, Inc.

Soltis, J. (1986). Teaching professional ethics, Journal of Teacher Education, 37 (2), 2-4. doi: $10.1177 / 002248718603700301$

University of Jordan (2019), Course Outline, Accreditation and Quality Control Center, electronic version.

Watras, J. (1986). Will teaching applied ethics improve schools of education? Journal of Teacher Education, 37(13), 13-16. doi:10.1177/002248718603700303.

Watts, L., Medeiros, K., Mulhearn, T., Steele, L., Connelly, S. and Mumford, M. (2016). Are Ethics Training Programs Improving? A Meta-Analytic Review of Past and Present Ethics Instruction in the Sciences. Ethics \& Behavior, 27 (5): 351 - 384.

Wenyeh, H. and Jonathan C. (2018). Improving Moral Reasoning among College Students: A Game-Based Learning Approach, Interactive Learning Environments, 26 (5): 583 - 596.

Winston, M. D. (2007). Ethical leadership and ethical decision making: A meta-analysis of research related to ethics education. Library \& Information Science Research, 29 (2): 230-251.

Yeazell, M., and Johnson, S. (1988). Levels of moral judgment of faculty and students in a teacher education program: A micro study of an institution. Teacher Education Quarterly, 15 (1): 61-70. 